\title{
Godsdienstige perspektiewe in die heropbou van die gemeenskap
}

D Crafford

\section{ABSTRACT}

\section{Religious perspectives in the reconstruction of the society}

The multi-religious context in South Africa is a fact and must be taken into account in any effort towards reconstruction and development of the society. The different religions are challenged to participate in the process of reconstruction. In many ways they can contribute positively towards the process. There are however also elements in religions which can hinder and obstruct the process. This article considers a number of perspectives in Islam, Hinduism, African Traditional Religion and Christianity which can have a positive or negative influence on the Reconstruction and Development Program in South Africa.

\section{INLEIDEND}

In die nuwe bedeling van die regering van nasionale eenheid in Suid-Afrika word 'n mens in 'n groeiende mate bewus van die land se multi-religieuse opset. Aanhangers van ander godsdienste speel 'n veel groter rol in politieke, ekonomiese en kulturele instellings. Vir baie Christene is dit 'n verleentheid wat hulle moeilik kan verwerk. Dit kan egter ook as 'n geleentheid tot samewerking gesien word op talle terreine.

Die Christene, wat bykans $80 \%$ van die bevolking uitmaak, is by verre die grootste groep. Die Afrika Tradisionaliste wat steeds afneem in getalle en baie aanhangers afstaan aan Onafhanklike Swart Kerke, mak nog steeds tussen $12 \%$ en $15 \%$ van die bevolking uit. Die invloed van tradisionele denke op die swart bevolking is egter veel groter as wat dié persentasie aandui. Moslems en Hindoes verteenwoordig elk minder as 2\% van die bevolking, maar speel 'n veel groter rol as wat hulle getalle mens sou laat dink vanweë hulle kontak met die invloedryke blokke van Islam en Hindoeïsme elders in die wêreld ${ }^{1}$. Hoewel elkeen van hierdie godsdienste 'n eie identiteit het en aanspraak kan maak op die vryheid om hulle geloof te beoefen ${ }^{2}$, is daar tog terreine waarop samewerking tussen die godsdienste 'n groot uitdaging geword het. 'n Mens dink hier aan terreine soos menseregte en menswaardigheid, bevolkingsontwikkeling, bekamping 
van vigs, bestryding van morele verval, misdaad en geweld en die opheffing van armoede en die lewenspeil van mense. Alle godsdienste het die ideaal om 'n beter wêreld te skep en om sinvol betekenis te gee aan die menslike bestaan in ' $n$ verwarde wêreld. Dit gee ten minste 'n grondslag vir samewerking ten spyte van die radikale verskille wat daar tussen hulle mag wees.

Dit is veral op die terrein van die heropbou en ontwikkeling van die breë Suid-Afrikaanse gemeenskap dat die verskillende godsdienste uitgedaag word om elkeen 'n bydrae te lewer tot opbou van die geheel. Hulle moet ook kyk of daar terreine is warop hulle kan saamwerk. In hierdie artikel wil ons kyk na 'n aantal religieuse motiewe wat 'n invloed kan hê op heropbou en ontwikkeling.

Te midde van die gebrokenheid, verskeurdheid en agterstande op talle gebiede wat in Suid-Afrikaanse gemeenskappe ervaar word, is ons almal maar te bewus van die behoefte aan heropbou en ontwikkeling. In 'n land waarin armoede, ongeregtigheid, ongelykheid, ongeletterdheid, geweld en misdaad hoogty vier, is die klem wat op heropbou gelê word eintlik vanselfsprekend. Vanuit 'n teologiese gesigshoek gesien, is die gebrokenheid waarin die wêreld hom bevind ook nie in ooreenstemming met God se wil nie. Hy het juis ingegryp om 'n stukkende, verlore en verknegte wêreld weer heel te maak, te verlos en te bevry. Hiertoe het Hy sy Seun in die wêreld ingestuur en sy Gees op pinksterdag uitgestort. Ons kan dus met reg sê dat heropbou en ontwikkeling in ooreenstemming met God se reddingsplan vir die wêreld is.

Ook by ander godsdienste wat in ons land teenwoordig is, is daar dimensies wat heropbou van die samelewing belangrik ag en daarom ook kan stimuleer. Die regering se heropbou- en ontwikkelingsplan kan nie slaag as daar nie aandag aan die godsdienstige dimensies gegee word nie. Die mens se verhouding tot God is primêr en daaruit vloei al die mens se ander verhoudinge. Die golf van misdaad, die verslawing aan dwelms en alkohol en die spiraal van geweld kan nie gestuit word indien mense se gesindhede nie deur godsdiens verander word nie. Daar word tans groot klem gelê op die materiële en ekonomiese aspekte van heropbou en ontwikkeling. Die verwaarlosing van geestelike aspekte kan egter tot die mislukking van die program lei. Godsdiens bepaal grootliks mense se motiewe en optrede. Dit het ook 'n invloed op mense se opvattings oor armoede en ontwikkeling.

Ons wil vervolgens let op 'n aantal godsdienstige modelle in ons land wat ' $n$ invloed kan hê op heropbou van die gemeenskap. Die rol wat hulle kan speel maar ook die gebreke van die modelle moet aangetoon word. 
Wanneer die muezzin op die minaret, die toring van die moskee, klim om mense op te roep tot gebed op Vrydag, roep hy uit: "Allah is die allergrootste, ek getuig dat daar geen god is behalwe Allah nie; ek getuig dat Mohammed die Apostel is van God. Kom en aanbid! Kom na die hoogste goed (Hayya al-Falāh)"3.

Die oproep na die goeie beteken 'n oproep na geluk, vrede en voorspoed wat die volk van God ervaar in sy teenwoordigheid. Dit is egter ook'n oproep om die goeie uit te leef in die gemeenskap van elke dag. Dit is 'n oproep tot die opbou en heel mak van die gemeenskap".

Vir Islam is die hoogste goed die absolute gehoorsaamheid an die wil van Allah soos geopenbaar in die Qur'an. Om 'n Moslem te wees beteken dan ook om in totale gehoorsaamheid aan Allah te lewe. 'n Moslem is dienskneg en slaaf van Allah. Daarby moet onthou word dat Islam die totale lewe van mense omspan en nie net 'n aspek daarvan nie. Daar word nie geskei tussen die pligte van die gelowige en dié van die staatsburger nie. Sosiale verpligtinge is religieus van aard en godsdiens word nie net in die moskee beoefen nie, maar ook in die markplek. Die oproep tot die daad - die doen van die goeie - is dus sowel 'n sosiale as 'n godsdienstige oproep. Islam omspan dus die geestelike, politieke, ekonomiese en wetenskaplike sfere van die lewes.

Die doen van wat goed is, word teruggevoer na die wil van Allah soos geopenbaar in die Qur'an. Daaruit is afgelei die Shariah - die universele wet wat 'n mens se totale lewe bepaal en jou sosiale verpligtinge omskryf. Die goddelike wet bepaal die totale lewe. Dit gee aan Islam 'n deur en deur wettiese karakter. Dit wat goed is word bepaal deur Allah, die profeet, die Qur'an, die tradisie en uiteindelik deur die Ummah - die gemeenskap wat die plig het om die tradisie te bewaar en te verklaar. Konsensus speel dus 'n groot rol in die bepaling van wat reg of verkeerd is ${ }^{6}$.

Die oproep tot Fallāh is dus 'n oproep tot die noukeurige onderhouding van die 5 pligte: die geloofsbelydenis (Shahadah); gebed (salät); vas (saum); gee van liefdadigheid, aalmoese (zakät) en die pelgrimstog na Mekka $\left(\right.$ Hajj $^{7}$.

Waar dit in hierdie artikel gaan om die sosiale verantwoordelikhede teenoor die minderbevoorregtes in die gemeenskap, gaan dit dus veral om die Zakāt - die gee van aalmoese. Die filosofie hieragter is dat daar groter gelykheid en geregtigheid in die samelewing moet bestaan ${ }^{8}$. In die Qur'an 
word ook die woord Sadaqãt vir aalmoese gebruik. Dit dui op geregtigheid en regverdigheid wat moet heers in die gemeenskap. Dit lê 'n plig op elke Moslem om vrywillige liefdadigheid en geregtigheid teenoor armes en noodlydendes te beoefen. Dit het die gewoonte van bedelary in Moslemlande laat toeneem ${ }^{9}$.

Die Zakät was egter min of meer 'n verpligte belasting van tussen $21 / 2 \%$ tot $10 \%$ van 'n persoon se inkomste. In Moslemlande word dit meestal aan die owerhede oorbetaal, maar elders word dit deur die geloofsgemeenskap self aangewend. Hieruit word armes, weduwees en weeskinders versorg, hulp aan vreemdelinge gebied en selfs slawe vrygekoop. Dit kan ook gebruik word vir onderwys en vir die stryd om die uitbreiding van Islam.

Moslemteoloë beskou Zakāt as 'n ideologie van sosiale verantwoordelikheid wat beter is as kapitalisme én kommunisme. Dit voorkom die uitbuiting van kapitalisme en besweer die gebrek aan private inisiatief by kommunisme. Uiteindelik is die doel om 'n meer eweredige verspreiding van besittings tussen ryk en arm te kry. Die rykes het 'n plig teenoor armes. Om te besit beteken ook om te deel. Eiendom word slegs in trust ontvang om weer te gebruik ten bate van die gemeenskap. Dit verklaar waarom daar meesal groot trustfondse onder Moslems beskikbaar is om vir verskillende vorme van liefdadigheid te gebruik ${ }^{10}$.

Zakät leer aan die Moslem sosiale verantwoordelikheid. Dit skerp sy gewete op om gehoorsaam te wees aan die wet. Die wet kan egter 'n swaar tugmeester wees. Daar is altyd die vraag of die gehoorsaamheid aan die wet genoegsaam uitgevoer is. Die wet verplig ook in die eerste plek hulp aan behoeftige Moslems. By al die goeie wat gedoen word binne die raamwerk van Zakät ontbreek tog soms die liefde. Plig sonder liefde, kan aan liefdadigheid so 'n wettiese karakter gee dat die egte medemenslikheid daaruit verdwyn.

Dit is duidelik dat Islam 'n teorie van sosiale verantwoordelikheid het wat mense oproep tot hulp aan minderbevoorregtes. Die wettiese karakter van 'n verpligte belasting skep tog 'n probleem. Die motief is op die ou end selfsug (my eie onderhouding van die wet) eerder as ware medelye met die behoeftige. Die idee van 'n belasting vir minderbevoorregtes funksioneer ook net in lande waar die Moslemwette verpligtend is. In Suid-Afrika, waar Moslems in die minderheid is, kan dit nie funksioneer nie. Die plig tot vrywillige liefdadigheid, skep 'n morele basis om Moslems op te roep tot samewerking in die bestryding van armoede. Ook hier is daar tekortkominge. Die gedagte van aalmoese uitdeel aan armes laat nie reg geskied aan hulle menswaardigheid nie. In Moslemlande het dit 
ook aanleiding gegee tot grootskaalse bedelary. Die gewer salf sy eie gewete en die ontvanger leer om afhanklik te word van aalmoese. Verder is Moslems geneig om vrywillige liefdadigheid te beperk tot geloofsgenote. Suid-Afrikaanse Moslems het al groot veldtogte geïnisieer om lydende Moslems elders in die wêreld te help. Daar is nog nie grootskaalse projekte aangepak vir die opheffing van swart gemeenskappe nie.

Ten spyte van bogenoemde kritiek is daar 'n gemeenskaplike ideaal tot sosiale verantwoordelikheid wat 'n basis vir samewerking tussen Moslems en Christene op hierdie gebied kan skep. Daar bestaan 'n morele basis van waaruit 'n oproep op Moslems gedoen kan word om deel te neem aan die heropbou en ontwikkelingsprogram (HOP) in Suid-Afrika. Hulle het toegang tot finansiële bronne in Arabiese lande wat groot steun vir die HOP-program sou kon verskaf. Tot dusver is Islam se bronne grootliks tot eie voordeel en uitbreiding aangewend. Hulle behoort uitgedaag te word om veel meer daarvan in te ploeg vir die opbou en ontwikkeling van dié gemeenskappe wat nie hulle geloof aanhang nie.

\section{DIE KARMA-MODEL: HINDOEISME}

In die Hindoeïsme word die goeie werke teenoor die noodlydende medemens grootliks bepaal deur die werking van karma. Karma is 'n Sanskrit-woord wat beteken aksie, handeling, daad. Dade van mense kan goed of sleg wees. Karma bepaal dat goeie dade beloon word en slegte dade gestraf word"1.

Karma is daardie geheimsinnige onpersoonlike kosmiese morele orde wat outomaties in werking tree om die goeie te beloon en die kwade te straf. Dit is dus 'n kosmiese wet dat 'n goeie daad geluk sal bring en 'n slegte daad ongeluk en ellende. Dit is dus ' $n$ verabsolutering van die beginsel van wat 'n mens saai, sal jy maai.

Karma word nou gekoppel aan die gedagte van Samsara. Samsara is die ewige wiel van inkarnasies van siele in hoër of laer vorms. Die wyse waarop ' $n$ reïnkarnasie gaan plaasvind, word deur karma bepaal. Wie goed geleef het, kon in die volgende lewe met 'n hoër sosiale status gebore word. Die wat sleg geleef het, kan in 'n laer vorm geïnkarneer word soos byvoorbeeld dié van 'n hond of 'n vark. Karma sal dus grootliks bepaal of 'n mens gebore word in die priesterklas, die soldateklas, die handelaarsklas of die arbeidersklas. Die klas waartoe 'n mens behoort, bepaal ook jou verpligtinge (dharma) in die samelewing.

Die probleem met karma is die onverbiddelike wyse waarop dit werk. Die straf volg outomaties en daar is geen ruimte vir berou of 
vergifnis nie. Die mens se lot word onverbiddelik deur sy eie dade bepaal. $\mathrm{Hy}$ is die slagoffer van 'n onverbiddelike kosmiese morele orde'2.

Karma verklaar die verskille wat tussen plante, diere en mense beștaan. Dit verklaar en bestendig ook die verskillende klasse in die samelewing. Dit verklaar verder die verskille tussen ryk en arm. Dit het tot gevolg dat armoede en ellende soms gelate in Hindoe-gemeenskappe aanvaar word. Dit is immers die gevolg van mense se eie optrede van die verlede wat hulle huidige lot bepaal. Daar kan dus nie veel daaraan gedoen word nie.

'n Mens kan egter deur jou goeie werke jou lot vir die toekoms verbeter. Een van die verlossingsweë in Hindoeïsme is die karma-marga. Dit is verlossing deur goeie dade. Deur onselfsugtige dade en deur die regte rituele handelinge kan 'n mens tog aan die wiel van reïnkarnasie ontsnap en deel word van die Al-Gees. Dit is verlossing Moksja. Dit moedig mense aan tot onbaatsugtige diens aan die naaste. Die hoogste werklikheid (Brahmaan) is teenwoordig in die armes, ellendiges, blindes, bedelaars en siekes. Diens aan hulle is ook diens aan die Brahmaan en dit kan help om uiteindelik ' $n$ eenheid met Hom te beleef ${ }^{13}$. Die karma-model spoor mense aan tot goeie werke om hoofsaaklik selfsugtige redes. Dit kan jou help om in ' $n$ volgende lewe in 'n beter posisie te wees of dit kan jou help om tot uiteindelike verlossing te kom.

Die religieuse pligte van die Hindoeïsme is grootliks gerig op die mistieke eenwording met die Al-Gees. Dit is in wese 'n religie wat eerder die wêreld wil ontvlug as om dit te wil verander en te verbeter. Die gevolg is dat Hindoes die sosiale gebrokenheid (soos wat dit byvoorbeeld in die Kaste-stelsel tot uiting kom) met groot gelatenheid kan aanvaar. Die minder bevoorregte het baie tyd om langs die weg van karma en talle reïnkarnasies sy eie posisie te verbeter in lewenssiklusse wat nog kom ${ }^{14}$. Die gedagte van hulp aan mense wat nie in die struktuur van Hindoeïsme leef nie, funksioneer nie. Die lot van die onaantasbares in Indië het dus treurig gebly en Hindoes het hulle min daaraan gesteur.

Daar is dus groot struikelblokke wat oorkom sal moet word voordat Hindoes op 'n groot skaal betrek sal kan word by deelname aan heropbou en ontwikkeling. Die Christelike ideale van barmhartigheid en geregtigheid en hulp aan almal wat in nood is, sal die tekortkominge in die Hindoeïsme moet aanvul ten einde 'n breë sosiale verantwoordelikheid te ontwikkel. 


\section{DIE BALANS VAN KOSMIESE KRAGTE-MODEL: AFRIKA TRADISIONELE GODSDIENSTE.}

Die kosmologie in Afrika bestaan uit 'n eenheid, 'n harmonie en totaliteit wat saamgestel is uit die Opperwese, die geeste, mense, diere, plante en lewelose dinge. Alles word in balans gehou deur 'n fyn balans van kosmiese kragte wat in mindere of meerdere mate in alle bestaande dinge voorkom. Die Opperwese is die bron van lewenskrag en die geesteswêreld die bemiddelaars daarvan. Op 'n beperkte wyse word dit beskikbaar aan mense, diere, plante en dinge. Die lewenskrag kan vermeerder of verminder word deur magiese handelinge.

Die sirkel is die simbool wat die beste uitdrukking gee aan die gevoel van heelheid en harmonie. Daarom is die tradisionele hut rond en die tradisionele stat 'n sirkel van hutte. So is die beeskraal en selfs die graf rond en die inkatha as simbool van die Zoeloevolk se eenheid is 'n spiraal. Binne die sirkel is lewe en eenheid, krag en harmonie, gemeenskap en beskerming. Buite die sirkel is gevaar en dood, siekte en chaos, eensaamheid en verval.

Die kosmiese totaliteit vind in die menslike samelewing en wel in die stam- en familieverband neerslag. Binne die kleiner en groter familie is daar dieselfde harmonie, beskerming, gemeenskap en voorspoed. Die mens voel hom een met die gemeenskap maar ook met die kosmiese totaliteit. Alles wat die harmonie bedreig, is uit die bose. Hierdie holistiese lewensen wêreldbeskouing het aan indiwidue en gemeenskappe geluk, sekuriteit, $\mathrm{krag}$, voorspoed, vrede en gemoedsrus verseker. Harmonie en welsyn hang daarvan af of die mens in hierdie totaliteit sy regte plek gevind en behou het.

Welsyn en geluk in Afrika hang dus ten nouste met die kosmiese balans en die harmonie in die stamgemeenskap saam. Wanneer dit verbreek word is die mens ontwrig en sielsongelukkig. Dit verklaar die ontwrigtende uitwerking van akkulturasie. Die groot klem op ware menswees, harmonie met die natuur en harmonie in die gemeenskap moet positief beoordeel word. Daar is egter ook aspekte van hierdie model wat ontwikkeling en die heropbou van die gemeenskap ernstig kan strem. Veral op drie terreine behoort die tradisionele model deur die Christelike evangelie verander en hervorm te word. 


\section{(a) Verandering van 'n geslote sakrale kosmos na 'n oop gedesakraliseerde kosmos}

In die tradisionele kosmologie is die heelal 'n geslote stelsel van kragte waarin alle voorwerpe met mekaar in verband staan en op mekaar invloed uitoefen. Van dié stelsel is die Opperwese en die mens ook deel. Daar is geen radikale verskil tussen Skepper en skepsels nie. Die mens word as mikro-kosmos en die Opperwese as makro-anthropos beskou. In hierdie geslote kosmos word alles in balans gehou deur kragte wat op alles inwerk. Dit is inderdaad 'n sakrale kosmos omdat dit gevul is met geeste en kragte. Die Opperwese is die bron van kosmiese lewenskrag wat ook in alle bestaande dinge aangetref word. In hierdie wêreld van geeste en kragte is die mens so vasgevang dat hy weinig vryheid van beweging en keuse het. $\mathrm{Hy}$ is ' $\mathrm{n}$ gevangene van die kosmiese kragte. Hy leef in voortdurende vrees vir mense wat die kragte kan beheers en manipuleer.

Onder die invloed van die evangelie moet hierdie geslote sakrale kosmos egter verander word in 'n oop, gedesakraliseerde kosmos. Dit beteken die erkenning van 'n persoonlike God wat volmagtig regeer oor sy skepping. Hy gebruik die mens as sy gevolmagtigde verteenwoordiger om te regeer oor die skepping. Die mens word dus bevry van die vrees vir geeste en kragte. Hy word nie meer deur die natuur gemanipuleer nie, maar kan self die natuur beheers. Die kosmos is nie meer ' $n$ heilige en onaanraakbare ruimte nie, maar 'n neutrale ruimte waar God aan die mens 'n roeping gee om sy kultuurtaak uit te oefen. Die wêreld moet dus gedesakraliseer word van die invloed van geeste en kragte. As die proses egter te ver gevoer word, word dit 'n totaal gesekulariseerde wêreld waarin daar geen plek meer is vir die transendente nie.

Wanneer bogenoemde oorgang plaasgevind het, sal die magiese benadering van die kosmos wat ingestel is op 'n manipulering van kragte, vervang kan word met 'n wetenskaplike benadering waarin die natuurwette geken en beheers kan word. Die rituele benadering waardeur die kosmiese kragte beheer moet word, sal vervang word met geloofsafhanklikheid van God en gebed. Voordat hierdie oorgang plaasgevind het, sal die basiese wette wat wetenskap en tegnologie beheers, nie begryp kan word nie.

(b) Verandering van 'n geslote sakrale stam-gemeenskap na 'n oop pluralistiese gemeenskap

Die tradisionele gemeenskap word oorheers deur die belange van die eie stamgroep. Alles wat tot voordeel van die stam is, is goed en alles wat tot 
nadeel is, is verkeerd. Die voorvadergeeste bewaar die stamtradisies en stamgebruike en dit mag nie verander word nie. Die teenwoordigheid van die voorvadergeeste as deel van die stam mak dit 'n sakrale gemeenskap. Die opperhoof is die verteenwoordiger van die Opperwese en die kosmiese kragte op aarde en as sakrale hoof oefen hy goddelike gesag oor die stam uit.

Deur die invloed van die evangelie moet hierdie gemeenskap verander na 'n oop pluralistiese gemeenskap waarin mense van ander stamme en groepe ook aanvaar word. Dit skep ruimte vir beïnvloeding wat weer op verandering en vernuwing van stamgebruike kan uitloop. Partikularisme kan nou verander word in 'n meer universalistiese benadering waar algemeen menslike norme en regte geld. Dit sal ruimte skep vir groter verdraagsaamheid teenoor andersdenkendes in die gemeenskap. Hulle is dikwels juis die mense wat verandering en vernuwing kan bevorder. Verdraagsaamheid en aanvaarding van mense van ander stamme en politieke oortuigings is juis in Suid-Afrika vandag van die grootste belang. Die geweldige beheptheid met lewenskrag, vitaliteit en vrugbaarheid in die gemeenskap as hoogste norm kan alleen so vervang word met ander norme soos byvoorbeeld diensbaarheid aan die medemens. Dit sal dus 'n totale verandering in wêreldbeskouing verg om die oordrewe vrugbaarheidskultus en onbeheersde bevolkingsaanwas te verander na 'n uitgangspunt van verantwoordelike ouerskap.

\section{(c) Verandering van rituele pligte na morele verantwoordelikhede}

In die tradisionele gemeenskap kom die kwaad altyd van buite die mens af in die vorm van rituele onreinheid, smet of toordery. Dit moet afgewend word deur rituele wassinge, reiniginge en afweer van toordery. Min ruimte word gelaat vir die mens se eie morele verantwoordelikheid en vir 'n sondebesef wat in die hart van die mens sy oorsprong het. Morele verantwoordelikheid teenoor God en die medemens kan alleen gevorm word deur die wet en die evangelie. Vir ontwikkeling en verandering is morele verantwoordelikheid teenoor God, die medemens en die lewensruimte van die mens egter 'n belangrike voorwaarde.

Hierdie paar terreine illustreer die belangrike rol wat die christelike evangelie te speel het in die verandering van basiese tradisionele lewensbeskouinge. Baie meer voorbeelde sou genoem kon word. Akkulturatiewe kragte is besig om die tradisionele godsdienste van Afrika af te takel omdat hulle hulle nie goed leen tot aanpassing en vernuwing nie. As alternatiewe sal Afrika moet gryp na die Christendom of Islam, Marxisme of naakte 
sekularisme of materialisme. Die kontinent kan maklik verval tot normlose samelewings waarin misdaad hoogty vier. Dit kan na die beste voorkom word as Christelike norme en beginsels nuwe sin en stabiliteit aan gemeenskappe in Afrika gee. Dit sal ook die deure vir verandering en vernuwing open en as geesteskrag dien waardeur dit verwesenlik kan word.

\section{DIE DANKBAARHEIDSMODEL: DIE CHRISTELIKE DIAKONAAT}

Die Christelike bewoënheid oor mense in nood spruit voort uit dankbaarheid van gelowiges vir die verlossing, bevryding en genesing wat God aan hulle skenk in Christus en deur die werking van die Heilige Gees.

\section{(a) Teologiese begronding van die diakonaat}

Die diakonaat vind sy begronding daarin dat God nie die gebrokenheid soos ons dit in 'n onvolmaakte wêreld ervaar wil legitimeer nie, maar dat Hy juis sy heilsplan in werking gestel het om te herstel en te vernuwe. Hy het ook aan die verloste mens as sy verteenwoordiger die opdrag gegee om helend, genesend en vertroostend in die gebroke wêreld werksaam te wees.

Slegs enkele lyne in die begronding van die diakonaat as Skriftuurlike mandaat kan hier aangestip word: Die diakonaat is eerstens gegrond in God se barmhartigheid en geregtigheid. As barmhartige en regverdige God voed $\mathrm{Hy}$ die hongeriges en klee die naaktes; genees die siekes, blindes en lydendes; versorg die vreemdelinge, weduwees en weeskinders; laat reg geskied aan die verdruktes en bevry die gevangenes (Vgl Eks 22:20-21; Lev 22:21; Deut 15:7-18; 24:17; Jes 58:5-7; Jer 7:6; Pss 82; 146:7-9;).

God se barmhartigheid en geregtigheid vind sy hoogtepunt in die geboorte en sterwe van Jesus Christus as die lydende kneg van die Here. In sy bewoënheid oor die lydende en verdrukte mens is Christus teken van God se barmhartigheid en instrument van God se regverdiging van sondaars. In die Pauliniese briewe word in die oproep om barmhartigheid telkens na die voorbeeld van Christus verwys ( 2 Kor 8:9,10 en Fil 1:5).

Die diakonaat in die gemeente word moontlik gemaak deur die Heilige Gees deur wie die gemeente as liggaam van Christus tot stand kom. Die Heilige Gees verander harde harte en skep 'n gesindheid van welwillendheid, liefde en barmhartigheid teenoor mekaar. Hy skenk die vrug van die Gees wat 'n lewe van diensbaarheid moontlik maak. Hy skryf die verbondswet in die harte van gelowiges en laat die liefde en barmhar- 
tigheid van Christus in hulle lewe gestalte kry. Hierdie trinitariese begronding konstitueer die eie aard van die kerklike diakonaat en onderskei dit van humanitêre hulpverlening. Dit spruit voort uit 'n lewende verhouding met God drie-enig en kan daarom ware hoop aan 'n lydende wêreld bring.

Dit moet onthou word dat die diakonaat ook binne bepaalde perspektiewe funksioneer. Eerstens funksioneer dit binne 'n verbonds-perspektief. God het 'n genadeverbond met sy volk gesluit waardeur hulle 'n bepaalde status en roeping ontvang. Binne die ruimte van die verbond word barmhartigheid en geregtigheid moontlik. Verbondskinders word opgeroep tot 'n verbondslewe van dankbaarheid. Dit maak diakonaat tot dankbaarheidsdiens. Mense wat soveel genade ontvang het, kan ook genade betoon.

Tweedens funksioneer die diakonaat binne koninkryksperspektief. Die Koning van die Koninkryk wil die beginsels van sy Koninkryk laat geld. Hiervan is barmhartigheid, geregtigheid, liefde en vrede belangrike elemente. Die Koninkryk breek in 'n gebroke werklikheid in en binne die ruimte van die Koninkryk word iets van God se barmhartigheid en geregtigheid beleef. Gelowiges word opgeroep om die beginsels van die Koninkryk in die konkrete lewenssituasie van lydende mense in 'n gebroke wêreld sigbaar te maak.

Derdens funksioneer die diakonaat in 'n eskatologiese perspektief. Dit funksioneer in die wete dat die volkome herstel van die gebrokenheid eers met die wederkoms sal geskied. Dit gee aan die diakonaat 'n voorlopige tekenkarakter. Dit rig tekens op van die komende volmaktheid. Dit is nietemin belangrike tekens van hoop vir die wêreld - tekens dat 'n volkome herstel op pad is. Dit rig tekens op van die Koninkryk wat nou reeds in 'n gebroke wêreld inbreek, maar wat eenmaal in sy volmaakte gestalte sal kom.

Dit alles wys heen na die feit dat die diakonaat 'n roeping en mandaat van die kerk van Christus in 'n gebroke wêreld is. Dit is die opdrag van die Here: "Wees harmhartig soos julle Vader in die hemel barmhartig is" (Luk 6:36). Die sentrale tema van die bergrede by Lukas is dat die dissipels barmhartigheid teenoor ander mense en in besonderheid ook teenoor hulle vyande moet bewys. Die gelykenis van die barmhartige Samaritaan (Luk 10) spel die aard en omvang en adres van die barmhartigheid duidelik uit.

Die nuwe verbondsvolk van God moet hulle lewe inrig volgens die Wet van die Koning wat gesê het: "Elkeen wat onder julle groot wil word, moet julle dienaar wees" (Mat 20:26). So is die grondslag van 'n dienende gemeente in "í lydende wêreld gelê. Die gemeente vind die sin van sy 
bestaan in diens aan die wêreld. Die gemeente moet sy verskeidenheid van gawes aanwend in diens van die ander. "As goeie bedienaars van die veelvuldige genade van God moet elkeen, namate hy 'n genadegawe ontvang het, die ander dien" (1 Pet 4:10).

So gesien, word die diakonaat 'n dankbaarheidsdiens en barmhartigheidsdiens wat die sigbare sy is van God se liefde vir 'n noodlydende wêreld. Dit is tegelyk die sigbare aspek van die getuienis en verkondiging dat God besig is om in Christus en deur die Heilige Gees die stukkende en sondige wêreld heel te mak. Dit alles sou net mooi teorieë bly indien die diakonaat nie gestalte vind in praktiese dade van barmhartigheid en geregtigheid van die kerk in die wêreld nie. Hieraan word ten slotte aandag gee.

\section{(b) Die diakonaat as praktiese daad van die kerk in die wêreld}

Die wyse waarop die diakonaat as handeling van die kerk in die wêreld gesien word, hang af van die konteks waarin mense leef en van die uitgangspunte waarvolgens hulle die Skrif verstaan.

In die bevrydingsmodel beleef mense hulle situasie as onderdrukking en hulle primêre strewe is na bevryding. God wil hulle uit 'n situasie van armoede en onderdrukking uitlei, maar hierin het hulle self ook 'n rol te speel. Die armes moet in opstand kom teen hulle situasie en politieke en kerklike drukgroepe vorm om hulle posisie te verbeter. Die kerk moet in die vorm van basisgemeentes self ' $n$ instrument van verandering en selfs rewolusie word. Die onregverdige gesagstrukture moet aangeval word en vernietig word sodat geregtigheid vir almal kan geskied. Hier val die klem op diakonaat as sosio-politieke handeling.

In die piëtiese model word die wêreld beleef as 'n plek vol sonde waaruit mense gered moet word. Binne die kring van gelowiges is daar vrede en beskerming. Die sondige wêreld kan beswaarlik verander word en daarom moet dit liewer vermy word. Armoede en lyding sal daar altyd wees totdat die nuwe aarde deur God geskep word. Barmhartigheid moet bewys word aan noodlydendes wat op jou weg kom, maar die vernuwing van die samelewing is nie die taak van die kerk nie. Hier val die klem op diakonaat as geïsoleerde dade van barmhartigheid en as verlossingshandeling.

Die koningryksmodel aanvaar dat die koninkryk van God inbreek en 'n werklikheid word in 'n sondige en gebroke wêreld. Die gelowige is geroep om mee te werk aan die koms van die omvattende koninkryk wat verlossing uit sonde en redding uit nood insluit. Die tekens van die 
koninkryk word hier reeds opgerig deur dade van barmhartigheid en geregtigheid. Die beginsels van die koninkryk word so ver moontlik in die samelewing ingedra hoewel die finale bevryding van nood en lyding eers met die voleinding sal plaasvind. Hier val die klem op diakonaat as dade van barmhartigheid en geregtigheid wat gerig is op die vergestalting van die omvattende koninkryk. Hier is diakonaat dus koninkrykshandeling.

Vanuit hierdie raamwerk van diakonaat as koninkrykshandeling word elke gelowige lidmaat, elke ampsdraer en elke gemeente opgeroep om deel te hê aan die heropbou van die gemeenskap en die genesing van die gebrokenheid waarin ons lewe. So lewer ons 'n bydrae tot die koms van God se koninkryk in 'n stukkende wêreld.

\section{SAMEVATTING}

Uit alles wat gesê is, is dit duidelik dat die godsdienstige dimensies in die opbou van die gemeenskap nie misgekyk mag word nie. Al die godsdienste in Suid-Afrika het perspektiewe wat die heropbou en ontwikkeling van die gemeenskap kan stimuleer. Dit behoort positief en konstruktief aangewend te word. Elemente wat dit strem behoort raakgesien en erken te word. In 'n proses van samewerking kan godsdienste mekaar se gebreke aanvul.

Waar Christelike kerke die oorgrote meerderheid van mense in ons land verteenwoordig, lê daar 'n groot verantwoordelikheid op die skouers van dié kerke om die uitdaging van heropbou en ontwikkeling raak te sien en konstruktief daaraan deel te neem. Die nodige ekumeniese strukture behoort geskep te word om daaraan uitvoering te gee.

Die mees primêre taak van die kerke bly steeds om mense tot geloof en bekering op te roep sodat hulle vanuit die regte verhouding tot God hulle ook in dankbaarheid en met barmhartigheid tot die medemens in nood kan wend. Daarna is dit die takk van kerke om deur 'n aktiewe diakonaat ook aan heropbou programme deel te neem om op dié wyse tekens op te rig van die teenwoordigheid van God se Koninkryk in die wêreld.

\section{NOTAS:}

1 J J Kritzinger, Die godsdiensmosaïek van Suid-Afrika, ISWEN, Universiteit van Pretoria 1986, 4.

2 N Koshy, Religious freedom in a changing world, Geneva 1992, 115.

3 K Cragg, The call of the minaret. New York 1956. 105.

4 Cragg, $a w, 140$. 
$5 \quad$ N Smart, The religious experience of mankind, New York 1984, 408.

6 E Moosa, "Islam" in: J W de Gruchy en M Prozesky, A Southern African guide to world religions, Kaapstad 1991, 210.

7 G C Oosthuizen, Die godsdienste van die wêreld, Pretoria 1977, 68.

$8 \quad$ Moosa, $a w, 233$.

$9 \quad$ Cragg, $a w, 151$.

$10 \quad$ Cragg, $a w, 153$.

11 Oosthuizen, $a w, 181$.

12 R C Zaehner, Hinduism, Oxford 1966, $102 \mathrm{ev.}$

13 P Maxwell en T Naidoo, "The religions of India", in: De Gruchy en Prozesky, $a w, 66$.

14 H C Wolf, "The Hindu tradition", in: S G Fry, J R King, E R Swanger \& H C Wolf, Great Asian religions, Grand Rapids 1984, 41. 